\title{
Identifikasi Populasi, Manajemen Usaha, dan Pola Pemasaran Ternak Sapi Potong di Kelompok Sumber Tani Kecamatan Kebawetan Kabupaten Kepahiang
}

\section{Identification of Population, Business Management, and Marketing Pattern of Beef Cattle in Sumber Tani Group, Kebawetan District, Kepahiang Regency}

\author{
B. Brata, E. Soestrisno, B. D. Setiawan*, dan H. P. Purba \\ Jurusan Peternakan, Fakultas Pertanian, Universitas Bengkulu, Bengkulu, 38371 - Indonesia \\ *Corresponding E-mail: bagusdimassetiawan@gmail.com \\ (Diterima: 20 Agustus 2020; Disetujui: 2 Oktober 2020)
}

\begin{abstract}
ABSTRAK
Tujuan penelitian ini untuk mengidentifikasi perkembangan populasi, manajemen usaha, dan pola pemasaran ternak sapi potong. Metode yang digunakan adalah sensus dengan sampel 20 orang peternak sebagai responden. Peubah dalam penelitian ini adalah identitas peternak, populasi ternak sapi potong, manajemen usaha pemeliharaan, serta pola pemasaran ternak. Hasil penelitian ini disajikan ke dalam bentuk tabel, selanjutnya dianalisis secara deskriptif anallist. Hasil yang didapatkan bahwa populasi ternak sapi potong sebanyak 81 ekor dalam satu tahun, usaha ternak sapi potong dipelihara secara intensif serta untuk pola pemasaran ternak sapi potong tersebut dipasarkan secara langsung kepada konsumen dengan kriteria penentuan berupa bibit dan harga terkini. Diharapkan dengan infromasi ini, usaha ternak sapi potong bisa berkembang baik serta bisa memberikan kontribusi positif dalam peningkatan manajemen usaha sapi potong yang berkelanjutan.
\end{abstract}

Kata kunci: populasi, manajemen usaha, pola pemasaran, sapi potong, Bengkulu

\section{ABSTRACT}

This research aimed to identify population development, business management, and marketing patterns of beef cattle. The method used is a census with a sample of 20 breeders as respondents. The observed changes are the identity of the farmer respondent, the cattle population of beef cattle, the management of maintenance efforts, and marketing patterns. The results of this study are presented in the form of tables and analyzed descriptively. The result is that the cattle population of 81 cattle is cut in one year, the cattle business is intensively maintained, and the marketing pattern of beef cattle is marketed directly to consumers with the criteria of determination in the form of seeds and current prices. It is hoped that with this information, the cattle business can develop well and can have a positive impact on improving the sustainable business management system.

Keywords: population, business management, marketing patterns, beef cattle, Bengkulu

\section{PENDAHULUAN}

Peternakan sapi potong adalah sumber daya penghasil bahan pangan berupa protein hewani yang memiliki nilai ekonomis tinggi dan penghasil daging merah terbesar dari ternak ruminansia terhadap produksi daging dalam negeri sehingga usaha ternak sapi potong ini berpotensi untuk dikembangkan sebagai peluang bisnis menguntungkan. Tetapi produksi daging secara Nasional belum bisa memenuhi permintaan tersebut, permasalahan utama adalah produktivitas ternak sapi yang masih belum optimal, hal ini memaksa untuk pemerintah melakukan import freder dari luar negeri, maka Indonesia ini khawatirkan menjadi menjadi negara net-importir untuk sapi bakalan terbesar di dunia (Diwyanto, 
2008).

Dirjen Peternakan dan Kesehatan Hewan (2017), menyatakan persediaan impor sapi bakalan sebanyak 800.000 ekor dan ke dalam bentuk daging beku setara dengan 781.117 ekor sapi serta populasi sapi potong dalam negeri tahun 2015-2016 sekitar 15,4 juta/ekor dan 16,1 juta/ekor dengan jumlah posisi pertumbuhan populasi ternak sapi potong di Indonesia saat ini hanya sekitar 4,36\% dari jumlah populasi ternak sapi potong yang ada saat ini. Produktivitas sapi potong di tetapkan dua faktor utama yaitu, genetik dan lingkungan.

Keberhasilan pada usaha peternakan sapi, terdapat tiga unsur penting, yakni: bibit, pakan, dan manajemen usaha atau pengolaan. Manajemen pemeliharaan usaha peternakan mencakup pada kegiatan: perkawinan, pakan ternak, perkandangan dan kesehatan ternak. Manajemen usaha ternak juga mencakup pada penanganan sistem hilir yaitu: pemasaran serta sistem pengaturan tenaga kerja (Abidin, 2002). Manajemen pola dan sistem usaha pemasaran adalah kegiatan memberikan produk dari produsen ke konsumen. Pola pemasaran merupakan topik utama dalam kegiatan ekonomi dan sektor agribisnis hilir. Peternak yang menghasilkan suatu produk usaha pasti menginginkan produknya sampai dan bisa diterima oleh konsumen yang harus melalui kegiatan pemasaran (Rahardi dan Hartono, 2003).

Berdasarkan letak geografisnya Desa Tangsi Duren ini berada di Kecamatan Kabawetan, Kabupaten Kepahiang Provinsi Bengkulu yang berbatasan di Utara dengan Desa Air Sempiang, di Timur dengan Desa Tugu Rejo, sebelah Selatan dengan Desa Wiskus, dan sebelah Barat dengan Kelurahan Tangsi Baru. Berdasarkan daftar isian tingkat perkembangan desa dan kelurahan pada tahun 2019, jumlah penduduk Desa Tangsi Duren 846 jiwa. Di Desa Tangsi Duren terdapat beberapa kelompok tani yang sudah berkembang dan salah satu kelompok tani yang ada dan sudah berkembang adalah Kelompok Tani Sumber Tani Makmur, yang memiliki anggota lebih kurang sebanyak 20 orang, kelompok tersebut sudah mengembangkan ternak sapi potong dari berbagai jenis ternak sapi potong; sapi bali, sapi limousin, sapi simmental dengan jumlah ternak sapi yang ada pada kelompok tersebut lebih kurang sebanyak 81 ekor. Berdasarkan penjelasan tersebut, adanya beberapa masalah terjadi pada usaha peternakan sapi potong di Kelompok Sumber Tani di Desa Tangsi Duren yakni; 1) harus adanya pengkajian pada populasi ternak sapi potong pada potensi daerah serta kepemilkannya; 2) mengkaji pada sistem manajemen usaha pemeliharaan ternak sapi potong dari produktivitasnya; dan 3) mengkaji pola pemasaran usaha ternak sapi potong sehingga nilai jual ternak menjadi tinggi.

\section{METODE}

\section{Materi Penelitian}

Penelitian dilakukan pada Kelompok Sumber Tani Desa,Tangsi Duren, Kecamatan Kebawetan, Kabupatenn Kepahiang, Provinsi Bengkulu. Pemilihan lokasi dilakukan secara purposive. Responden pada penelitian ini ialah seluruh anggota Kelompok Sumber Tani yang memelihara sapi potong yang ada di Desa Tangsi Duren, Kecamatan Kabawetan, Kabupaten Kepahiang, Provinsi Bengkulu dengan jumlah sampel ditetapkan secara sensus yaitu 20 orang peternak sebagai responden.

\section{Metode Penelitian}

Data dalam penelitian ini merupakan data primer dan data sekunder. Data primer didapatkan dengan cara pengamatan secara langsung ke lokasi penelitian dengan cara wawancara langsung (dept interview) ke kelompok peternak dengan menunjukkan kuisioner sebagai alat dalam penelitian ini untuk bisa mendapatkan informasi yang di butuhkan dari peternak. Data primer terdiri pada: identitas responden, populasi ternak, manajemen usaha pemeliharaan (manajemen bibit sapi, sistem reproduksi ternak sapi, sistem pemberian pakan dan pemberantasan 
penyakit), dan pola pemasaran usaha ternak sapi potong, data sekunder didapatkan dari hasil: laporan, buku, catatan, penelitian yang mendukung pada penelitian ini. Data sekunder didapat pada intansi pemerintahan, lembaga, jurnal, e-book, buku yang berkaitan dengan penelitian pada literature dan pustaka yang relevan.

\section{Peubah Yang Diamati}

Peubah yang diamati dalam penelitian ini adalah sebagai berikut:

1. Karakteristik Identitas Responden peternak sapi potong;

2. Populasi ternak berupa: jumlah ternak (induk, jantan, anak) dan jumlah kematian;

3. Manajemen Pemeliharaan meliputi:

a. Bibit ternak: bibit sapi, asal bibit, jenis bibit, umur bibit, dan bobot bibit;

b. Reproduksi ternak: sistem perkawinan, rasio jantan dan betina, perlakuan pejantan dan betina pada saat kawin;

c. Pakan ternak: waktu pemberian pakan, frekuensi pemberian pakan, jumlah pemberian pakan, ketersediaan pakan, jenis pakan yang diberikan;

d. Sanitasi kandang ternak, dilakukan agar ternak terhindar dari penyakit yang bisa menurunkan produktifitas usaha;

e. Pencegahan penyakit pada ternak sapi potong: pemberian obat apa, waktu pencegahan penyakit, sanitasi, dan vitamin;

f. Pasca panen, cara penjualan produksi ternak sapi potong, harga pemasaran ternak sapi potong.

4. Pola Pemasaran.

Pola pemasaran ternak sapi potong ini meliputi pada: cara penjualan ternak sapi potong, kriteria penentuan harga ternak, dan waktu penjualan ternak sapi potong.

\section{Analisis Data}

Data yang didapatkan selanjutnya akan ditabulasi dan data akan disajikan dalam bentuk tabel dan dibahas secara deskriptif melalui perbandingan dengan hasil penelitian yang mendukung.

\section{HASIL DAN PEMBAHASAN}

\section{Identitas Responden}

Usaha peternakan sapi potong pada umumnya adalah usaha dengan skala yang masih relatif kecil atau sebagai usaha peternakan rakyat sehingga dasarnya hanya bisa dapat menggunakan SDM/tenaga kerja keluarga. Pemeliharaan ternak yang diusahakan oleh peternak masih pada bersifat tabungan/ dapat dijual kapan pun dan sebagian besar mata pencaharian masyarakat di wilayah Desa Tangsi Duren ialah bertani. Karekteristik Identitas responden yang diamati adalah: jumlah responden, alamat responden, umur responden, pendidikan terakhir, pekerjaan utama, lama pemeliharaan, serta tujuan dari pemeliharaan ternak sapi potong.

Jumlah responden sebanyak 20 orang dari kelompok Sumber Tani Makmur di Desa Tangsi Duren (Tabel 1). Umur responden bervariasi, umur tertua pada kisaran 52 tahun dan termuda 28 tahun. Umur responden 20-30 tahun sebanyak (20\%), 31-40 tahun sebanyak (30\%), 41-50 tahun sebanyak (45 $\%$ ), dan 51-60 tahun sebnyak (5\%). Tingkat pendidikan peternak terbanyak berada pada tingkat SMA sebanyak 8 orang atau (40 $\%$ ). Sebagian besar responden memiliki pengalaman berternak sekitar 21-30 tahun. Umur yang masih produktif merupakan suatu modal utama pada kegiatan pengembangan usaha peternakan. Kemampuan dan fisik manusia akan optimal jika berada pada umur yang produktif, usia yang masih produktif adalah berkisar antara 25-64 tahun (Setiawan, 2019).

\section{Populasi Ternak Sapi Potong}

Perlu adanya usaha peningkatan populasi ternak sapi potong ini untuk mendukung pembangunan peternakan di seluruh penjuru wilayah Indonesia (Amin et al., 2019). Hal ini perlu untuk ditingkatkan, karena mengingat akan kebutuhan daging ternak sapi potong yang ada di Indonesia 
Tabel 1. Identitas Responden Penelitian di kelompok Sumber Tani Makmur Desa Tangsi Duren, Kecamatan Kabawetan, Kabupaten Kepahiang

\begin{tabular}{|c|c|c|c|}
\hline No & Identitas Responden & Jumlah (Orang) & Persentase (\%) \\
\hline \multirow[t]{3}{*}{1} & Jenis Kelamin & & \\
\hline & Laki - laki & 20 & 100 \\
\hline & Perempuan & 0 & 0 \\
\hline \multirow[t]{5}{*}{2} & Kelompok umur (tahun) & & \\
\hline & $20-30$ & 4 & 20 \\
\hline & $31-40$ & 6 & 30 \\
\hline & $41-50$ & 9 & 45 \\
\hline & $51-60$ & 1 & 5 \\
\hline \multirow[t]{5}{*}{3} & Tingkat Pendidikan & & \\
\hline & $\mathrm{SD}$ & 4 & 20 \\
\hline & SMP & 7 & 35 \\
\hline & SMA & 8 & 40 \\
\hline & SMK & 1 & 5 \\
\hline \multirow[t]{5}{*}{4} & Lama Beternak (tahun) & & \\
\hline & $1-10$ & 3 & 15 \\
\hline & $11-20$ & 6 & 30 \\
\hline & $21-30$ & 10 & 50 \\
\hline & $31-40$ & 1 & 5 \\
\hline \multirow[t]{3}{*}{5} & Tujuan Pemeliharaan & & \\
\hline & Penggemukan & 16 & 80 \\
\hline & Pembibitan & 4 & 20 \\
\hline
\end{tabular}

meningkat dari setiap tahunya. Sejalan dengan meningkatnya kesadaran masyarakat akan kebutuhan protein sebagai gizi asal dari ternak sapi potong ini, akan tetapi belum dapat diimbangi dengan sistem peningkatan populasi ternak. Jumlah keseluruhan ternak sapi yang dimiliki kelompok tani Sumber Tani Makmur Desa Tangsi Duren sebanyak 81 ekor dalam satu terakhir. Populasi ternak sapi ini terdiri dari induk menyusui 7 ekor atau $33 \%$, induk masa kosong 27 ekor atau 33\%, pejantan 33 ekor atau $41 \%$, anakan 7 ekor atau 9\%, dan dara 7 ekor atau 9\% (Tabel 2).

Populasi ternak sapi potong yang ada pada kelompok ini didapatkan dengan jumlah ternak betina dewasa relatif yang cukup tinggi $41 \%$ hal ini mendukung pada program breeding farm people. Tetapi pada persentase kelahiran anakan relatif lebih rendah 7\%, hal ini dapat mempengaruhi perbandingan antara ternak sapi di daerah ini di tahun berikutnya. Kelompok ini memiliki populasi ternak sapi betina yang rendah untuk dikembangbiakkan menyebabkan pedet yang lahir sedikit sehingga menurunkan populasi ternak sapi potong. Rendahnya persentase dari anakan sapi kelompok ini disebabkan terjadinya in breeding sehingga menurunkan peforma dan reproduksi. Penurunan angka kelahiran ini dipengaruhi oleh efesiensi reproduksi atau kematian prenatal (Teolihere, 1983 dalam Afriani et al., 2019).

Jumlah populasi ternak sapi potong merupakan salah satu faktor penentu tinggi rendahnya hasil pendapatan usaha. Hal ini sesuai dengan pendapat dari Murwanto (2008) 
Tabel 2. Populasi Ternak sapi potong di kelompok Sumber Tani Makmur Desa Tangsi Duren, Kecamatan Kabawetan, Kabupaten Kepahiang

\begin{tabular}{clcc}
\hline No & Uraian & Jumlah & Persentase (\%) \\
\hline 1 & Induk bunting & 0 & 0 \\
2 & Induk menyusui & 7 & 9 \\
3 & Indukmasa kosong & 27 & 33 \\
4 & Pejantan & 33 & 41 \\
5 & Anakan & 7 & 9 \\
6 & Dara & 7 & 9 \\
\hline Jumlah & & 81 & 100 \\
\hline
\end{tabular}

yang menyatakan meningkatnya jumlah sapi yang dimiliki maka jumlah sapi yang dijual akan bertambah jumlah sapi yang dijual, dengan demikian pendapatan meningkat dan meningkatnya jumlah ternak sapi potong yang dimiliki menunjukkan pula skala usaha pemeliharaan yang dimiliki. Menurut Sugeng (2007) usaha ternak sapi potong akan dapat menguntungkan jika minimal jumlah sapi potong yang dimiliki oleh peternak adalah 10 ekor dengan persentase produtivitas sapi $>60 \%$. Peternakan sapi potong di kelompok Tani Sumber Tani Makmur Desa Tangsi Duren perlu ditingkatkan lagi hingga masingmasing anggota memiliki ternak minimal 10 ekor sapi potong (Tabel 2) untuk mencapai titik yang efisien untuk mendukung pada pengembangan peternakan di Indonesia, maka harus diberikan kepada peternakan rakyat yang merupakan bagian terbesar dari peternak di Indonesia.

\section{Manajemen Pemeliharaan}

Pemilihan bibit merupakan salah faktor yang berperan dalam proses pemeliharaan. Untuk pemilihan bibit ternak sapi potong adalah asal bibit, jenis bibit, bobot bibit. Peternak di kelompok Sumber Tani Makmur Desa Tangsi Duren memperoleh bibit sapi potong dari blantik, yakni pada 3 peternak atau $15 \%$, dari peternak lain 8 peternak atau $40 \%$ dan sisanya adalah hasil peranakan sebanyak 9 peternak atau 45\% . Dalam pemilihan bibit sapi potong ini, kelompok tani Sumber Tani Makmur lebih dominan memlih bibit jenis sapi bali, yaitu sebanyak 18 ekor ternak sapi
Bali atau $90 \%$, sedangkan sisanya memilih bibit Simmental sebanyak 1 ekor atau 5\% dan Limousin dengan jumlah 1 ekor atau 5\% (Tabel 3).

Dalam upaya menghasilkan bibit ternak sapi potong yang baik dan berkualitas, bisa dengan cara melakukan seleksi bibit yang berkualitas (Setiawan, 2019). Seleksi dapat dapat dilakukan dengan memilih ternak yang mempunyai mutu genetik yang bagus utuk bisa dikembangkan secara lebih lanjut serta dalam memilih ternak yang kurang baik dapat dipisahkan dari bibit yang berkualitas bagus. Seleksi dapat dilakukan pada melihat genetik dan sifat ternak. (Hafez and Hafez, 2013). Kriteria seleksi bibit bekalan ternak sapi yang bagus/baik menurut Direktorat Pembibitan Ternak (2012) adalah pada: 1) kesesuaian warna tubuh dengan bangsa sapi, baik pada sapi lokal maupun pada sapi luar; 2) melihat serta memeriksa recording ternak nya untuk mengetahui riwayat hidup ternak hidupnya sejak lahir (genetik induknya, tanggal lahir, berat lahir, serta penyakit yang pernah di alami); dan 3) sehat (aktif, raktif dan peka, nafsu makan tinggi, tidak ada luka, mata jernih, bulu halus dan bersih mengkilap, tidak kusam, bokong bersih dan padat); 4) bentuk badan panjang, kaki pendek dan kuat, dada lebar dan dalam; 5) seleksi bibit berdasarkan tinggi badan untuk masing- masing bangsa berbeda diantaranya pemilihan tergantung pada bibit nasional, seleksi tergantung kepada standart populasi; 6) umur ternak 1-2 tahun (sapi muda) dan 2-3 tahun (sapi dewasa); 
Tabel 3. Pemilihan bibit ternak ternak di kelompok Sumber Tani Makmur Desa Tangsi Duren, Kecamatan Kabawetan, Kabupaten Kepahiang

\begin{tabular}{|c|c|c|c|}
\hline No & Uraian & Jumlah & Persentase $(\%)$ \\
\hline \multirow[t]{5}{*}{1} & Bibit Ternak & & \\
\hline & Anakan & 18 & 90 \\
\hline & Dara & 1 & 5 \\
\hline & Indukan & 1 & 5 \\
\hline & Total & 20 & 100 \\
\hline \multirow[t]{5}{*}{2} & Umur Bibit (bulan) & & \\
\hline & $1-5$ & 12 & 60 \\
\hline & $6-10$ & 7 & 35 \\
\hline & $11-15$ & 1 & 5 \\
\hline & Total & 20 & 100 \\
\hline \multirow[t]{5}{*}{3} & Asal Bibit & & \\
\hline & Blantik & 3 & 15 \\
\hline & Peternak lain & 8 & 40 \\
\hline & Peranakan & 9 & 45 \\
\hline & Total & 20 & 100 \\
\hline \multirow[t]{5}{*}{4} & Jenis Bibit & & \\
\hline & Sapi Bali & 18 & 90 \\
\hline & Simmental & 1 & 5 \\
\hline & Limousin & 1 & 5 \\
\hline & Total & 20 & 100 \\
\hline \multirow[t]{6}{*}{5} & Bobot sapi (Kg) & & \\
\hline & $10-50$ & 5 & 25 \\
\hline & $51-100$ & 4 & 20 \\
\hline & $101-150$ & 8 & 40 \\
\hline & $151-200$ & 3 & 15 \\
\hline & Jumlah & 20 & 100 \\
\hline
\end{tabular}

7) bentuk kerangka yang besar dan panjang (kepala dan moncong besar, tulang punggung lurus serta bulu halus); dan 8) calon indukan sudah menunjukan birahi pertama pada umur $\leq 18$ bulan, service per conception $(\mathrm{S} / \mathrm{C}) \leq 2$, dan $\mathrm{CI} \leq 14$ bulan.

\section{Manajemen Reproduksi Ternak Sapi}

Kemampuan reproduksi pada jenis ternak sapi, bisa dilihat dengan penampilan reproduksi ternak tersebut. Adapaun untuk umur ternak dikawinkan mulai dari umur 10-15 bulan sebanyak 5 peternak 5 peternak
(83\%), dan umur 16-20 bulan sebanyak 1 peternak (17\%) (Tabel 4). AAK (2011) menyatkan bangsa sapi tropis mengalami dewasa kelamin pada usia 1,5-2 tahun dan mencapai dewasa tubuh 2-2,5 tahun, maka sapi dapat dikawinkan secara tepat. Sistem perkawinan ternak yang dilakukan oleh kelompok Sumber Tani Makmur Desa Tangsi Duren, Kecamatan Kabawetan, Kabupaten Kepahiang adalah dengan sistem kawin suntik atau inseminasi buatan (IB). disebabkan pada ternak sapi jantan dewasa yang di pelihara hanya dijadikan pemancing dan ternak sapi 
Tabel 4. Manajemen reproduksi ternak sapi potong di kelompok Sumber Tani Makmur Desa Tangsi Duren, Kecamatan Kabawetan, Kabupaten Kepahiang

\begin{tabular}{|c|c|c|c|}
\hline No & Uraian & Jumlah & Persentase $(\%)$ \\
\hline \multirow[t]{5}{*}{1} & Rasio pejantan dan betina & & \\
\hline & $0: 0-0: 5$ & 1 & 5 \\
\hline & $1: 1-1: 5$ & 12 & 60 \\
\hline & $2: 0-2: 5$ & 7 & 35 \\
\hline & Total & 20 & 100 \\
\hline \multirow[t]{4}{*}{2} & Umur ternak dikawinkan (bulan) & & \\
\hline & $10-15$ & 5 & 83 \\
\hline & $16-20$ & 1 & 17 \\
\hline & Total & 6 & 100 \\
\hline \multirow[t]{3}{*}{3} & Lama kebuntingan (hari) & & \\
\hline & 278 & 6 & 100 \\
\hline & Total & 6 & 100 \\
\hline \multirow[t]{3}{*}{4} & Penanganan saat melahirkan & & \\
\hline & tidak ada & 6 & 100 \\
\hline & Total & 6 & 100 \\
\hline \multirow[t]{3}{*}{5} & Lama menyusui (hari) & & \\
\hline & 90 & 6 & 100 \\
\hline & Total & 6 & 100 \\
\hline \multirow[t]{3}{*}{6} & Ternak kastrasi & & \\
\hline & tidak ada & 20 & 100 \\
\hline & Total & 20 & 100 \\
\hline \multirow[t]{4}{*}{7} & Umur sapi siap sapih (bulan) & & \\
\hline & $3-4$ & 8 & 40 \\
\hline & $5-6$ & 12 & 60 \\
\hline & Total & 20 & 100 \\
\hline \multirow[t]{4}{*}{8} & Jenis perkawinan & & \\
\hline & Alami & 0 & 0 \\
\hline & IB & 6 & 100 \\
\hline & Total & 6 & 100 \\
\hline \multirow[t]{3}{*}{9} & Jumlah kelahiran & & \\
\hline & 1 tahun & 6 & 100 \\
\hline & Jumlah kelahiran & 6 & 100 \\
\hline
\end{tabular}

jantan di kelompok ini hanya digemukan selanjutnya dijual untuk di potong.

Untuk lama kebuntingan ternak sapi di kelompok tani Sumber Tani Makmur adalah selama 278 hari sebanyak 6 peternak $(100 \%)$. Di kelompok tani Sumber Tani Makmur dalam hal penanganan saat lahiran tidak ada, lama menyusui ternak sapi di kelompok tani Sumber Tani Makmur adalah 90 hari sebanyak 6 peternak (100\%). Umur anak sapi siap di sapih di kelompok tani Sumber Tani Makmur adalah 3-4 bulan sebanyak 8 peternak (40 
Tabel 5. Data Manajeman Pakan di kelompok Sumber Tani Makmur Desa Tangsi Duren, Kecamatan Kabawetan, Kabupaten Kepahiang

\begin{tabular}{|c|c|c|c|}
\hline No & Uraian & Jumlah & Persentase $(\%)$ \\
\hline \multirow[t]{2}{*}{1} & Jenis Pakan utama & & \\
\hline & Rumput & 20 & 100 \\
\hline \multirow[t]{2}{*}{2} & Sumber pakan & & \\
\hline & Tangsi Duren & 20 & 100 \\
\hline \multirow[t]{2}{*}{3} & Frekuensi Pemberian pakan & & \\
\hline & 2 kali/ hari & 20 & 100 \\
\hline \multirow[t]{2}{*}{4} & waktu pemberian & & \\
\hline & Pagi dan Sore & 20 & 100 \\
\hline \multirow[t]{4}{*}{5} & Jumlah pemberian pada anakan $(\mathrm{kg})$ & & \\
\hline & $20-40$ & 1 & 14 \\
\hline & $41-60$ & 3 & 43 \\
\hline & $61-80$ & 3 & 43 \\
\hline \multirow[t]{4}{*}{6} & Jumlah pemberian pada dara $(\mathrm{kg})$ & & \\
\hline & $20-40$ & 2 & 29 \\
\hline & $41-60$ & 3 & 43 \\
\hline & $61-80$ & 2 & 29 \\
\hline \multirow[t]{4}{*}{7} & Jumlah pemberian pada indukan (kg) & & \\
\hline & $20-40$ & 9 & 50 \\
\hline & $41-60$ & 4 & 22 \\
\hline & $61-80$ & 5 & 28 \\
\hline \multirow[t]{4}{*}{8} & Jumlah pemberian pada jantan $(\mathrm{kg})$ & & \\
\hline & $20-40$ & 9 & 47 \\
\hline & $41-60$ & 5 & 26 \\
\hline & $61-80$ & 5 & 26 \\
\hline
\end{tabular}

$\%)$, dan 5-6 bulan (60\%). Dengan jumlah anak yang lahir dalam waktu 1 tahun terakhir adalah 6 ekor $(100 \%)$. Jumlah pedet yang lahir dalam waktu 1 tahun terakhir adalah 6 ekor (100\%). Jumlah rataan umur sapih pada ternak sapi di kelompok ini ialah 3-6 bulan. Dengan jarak beranak pada penelitian ini masih ideal, karena jarak beranak yang ideal yakni berkisar 365 hari (12 bulan) (Direktorat Jenderal Peternakan, 1998).

\section{Manajemen Pemberian Pakan}

Pakan yang diberikan di kelompok Sumber ini yakni berupa rumput sebanyak 20 peternak (100\%), adapun pakan berasal dari
Desa Tangsi Duren itu sendiri sebanyak 20 peternak (100\%). Pada umumnya peternak di kelompok tani Sumber Tani Makmur Desa Tangsi Duren Kabupaten Kepahiang sudah memberikan hijauan seperti rumput raja (Pennisetum purpureophoides), rumput setaria (Setaria spacelata), rumput gajah (Pennisetum purpureum), dan rumput lapang (Axonopus compressus).

Untuk frekuensi pemberian pakan di kelompok tani Sumber Tani Makmur adalah 2 kali per hari sebanyak 20 peternak $(100 \%)$, waktu pemberian adalah pagi dan sore. Jumlah pemberian pakan pada anakan 
Tabel 6. Manajemen pencegahan penyakit di kelompok Sumber Tani Makmur Desa Tangsi Duren, Kecamatan Kabawetan, Kabupaten Kepahiang

\begin{tabular}{|c|c|c|c|}
\hline No & Uraian & Jumlah & Persentase $(\%)$ \\
\hline \multirow[t]{3}{*}{1} & Sanitasi kandang & & \\
\hline & Ada & 20 & 100 \\
\hline & Tidak ada & 0 & 0 \\
\hline \multirow[t]{2}{*}{2} & Pencegahan Penyakit & & \\
\hline & Sanitasi kandang & 6 & 100 \\
\hline \multirow[t]{3}{*}{3} & Penyakit yang sering terjadi & & \\
\hline & Caingan & 4 & 67 \\
\hline & Kembung & 2 & 33 \\
\hline \multirow[t]{3}{*}{4} & Penggunaan obat tradisional & & \\
\hline & Jamu & 6 & 75 \\
\hline & Minyak makan & 2 & 25 \\
\hline \multirow[t]{2}{*}{5} & Penggunaan obat kimia & & \\
\hline & Wormzol - B & 4 & 100 \\
\hline \multirow[t]{2}{*}{6} & Pemandian ternak & & \\
\hline & Tidak ada & 20 & 100 \\
\hline \multirow[t]{3}{*}{7} & Menangani ternak sakit & & \\
\hline & Dokter hewan & 4 & 67 \\
\hline & Peternak & 2 & 33 \\
\hline \multirow[t]{2}{*}{8} & Program vaksin & & \\
\hline & Tidak ada & 20 & 100 \\
\hline \multirow[t]{4}{*}{9} & Waktu pemberian obat & & \\
\hline & Sebelum terserang & 0 & 0 \\
\hline & Sedang terserang & 6 & 100 \\
\hline & Tidak mengobati & 0 & 0 \\
\hline
\end{tabular}

di kelompok tani Sumber Tani Makmur adalah $20-40 \mathrm{~kg}$ sebanyak 1 peternak (14\%), 41- $60 \mathrm{~kg}$ sebanyak 3 peternak (43\%), dan 61-80 kg sebanyak 3 orang peternak (43\%). Pemberian pakan pada dara adalah $20-40 \mathrm{~kg}$ adalah 2 peternak (29\%), $41-60 \mathrm{~kg}$ sebanyak 3 peternak (43\%), dan 61-80 kg sebanyak 2 peternak $(29 \%)$. Pemberian pakan indukan adalah $20-40 \mathrm{~kg}$ sebanyak 9 peternak (50\%), 41- $60 \mathrm{~kg}$ sebanyaka 4 peternak (22\%), 61$80 \mathrm{~kg}$ sebanyak 5 peternak (28\%). Pemberian pakan pada pejantan adalah $20-40 \mathrm{~kg}$ sebanyak 9 peternak (47\%), 41-60 kg sebanyak 5 peternak (26\%) dan 61- $80 \mathrm{~kg}$ sebnyak 5 peternak (26\%). Santoso (2005) menyatakan prinsip hijauan diberikan yakni $10 \%$ dari BB sapi, yaitu berkisar antara 30-40 kg/ekor/ hari (Tabel 5). Pemberian pakan sebanyak 2 sampai 3 kali dalam sehari. Kurniawati et al. (2019) menyatakan pakan konsentrat diberikan 3-4 bulan menjelang akhir pada sistem penggemukan, umumnya diberikan sebanyak 1,5\% dari bersat badan hidup atau 3 sampai $4 \mathrm{~kg} / \mathrm{ekor} /$ hari.

\section{Manajemen Pencegahan Penyakit}

Berdasarkan hasil pengamatan dan wawancara di lapangan, penerapan sapek kesehatan ternak sapi di kelompok tani Sumber Tani Makmur masih tergolong rendah. Hal ini terlihat dari minimnya pengetahuan peternak 
Tabel 7. Data panen ternak di kelompok Sumber Tani Makmur Desa Tangsi Duren, Kecamatan Kabawetan, Kabupaten Kepahiang

\begin{tabular}{|c|c|c|c|}
\hline No & Uraian & Jumlah & Persentase $(\%)$ \\
\hline \multirow[t]{4}{*}{1} & Umur panen (bulan) & & \\
\hline & $5-10$ & 3 & 27 \\
\hline & $11-20$ & 7 & 64 \\
\hline & $>21$ & 1 & 9 \\
\hline \multirow[t]{4}{*}{2} & Kriteria penjualan & & \\
\hline & Anakan & 1 & 9 \\
\hline & Induk & 3 & 27 \\
\hline & Potong & 7 & 64 \\
\hline \multirow[t]{4}{*}{3} & Pola pemasaran & & \\
\hline & Tengkulak & 10 & 91 \\
\hline & Konsumen & 0 & 0 \\
\hline & Peternak lain & 1 & 9 \\
\hline \multirow[t]{7}{*}{4} & Harga jual ternak & & \\
\hline & Anakan & & \\
\hline & Rp14.000.000 & 1 & 9 \\
\hline & Indukan & & \\
\hline & Rp 10.000.000 - Rp 15.000.000 & 9 & 82 \\
\hline & Jantan & & \\
\hline & Rp24.000.000 & 1 & 9 \\
\hline 5 & Jumlah Ternak dijual & 12 & 15 \\
\hline
\end{tabular}

tentang penyakit ternak. Dalam pelaksanaan sanitasi kandang peternak di kelompok tani Sumber Tani Makmur, peternak sudah melaksanakannya. Penyakit yang sering menyerang ternak di kelompok Sumber Tani Makmur adalah cacingan sebanyak 4 peternak $(67 \%)$, dan kembung sebanyak 2 peternak (33\%) (Tabel 6). Cacingan merupakan panyakit dapat menimbulkan gejala seperti : tubuhnya kurus, nafsu makan kurang, bulu kusam, tidak agresif, cacing dapat di cegah dan diobati dengan memberikan obat cacing. Jenis obat yang diberikan pada ternak cacingan adalam Wormzol- B.

\section{Pasca Panen Tenak Sapi Potong}

Berdasarkan hasil penelitian yang didapatkan dari lapangan, di kelompok tani Sumber Tani Makmur Desa Tangsi duren, peternak menjual ternak anakan, induk, dan potong. Di kelompok tani Sumber Tani Makmur, peternak menjual anakan pada umur 5 bulan sebanyak 1 ekor (9\%), indukan 3 ekor umur 7 bulan, 13 bulan dan 20 bulan sebanyak 3 ekor (27\%), dan potong sebanyak 7 ekor (64\%) umur 10 bulan, 11 bulan, 12 bulan 3 ekor, 14 bulan, dan 36 bulan. Pola pemasaran yang dilakukan peternak di kelompok tani Sumber Tani Makmur adalah melalui tangkulak 10 orang peternak $(91 \%)$, dan 1 orang menjual langsung ke peternak lain $(9 \%)$. Harga penjualan ternak sapi di kelompok Sumber Tani Makmur, Kabupaten Kepahiag ini bervariasi berdasarkan vase umur ternak yaitu anakan dijual 1 ekor dengan harga Rp 14.000.000, indukam dijual 9 ekor ternak dengan harga $\mathrm{Rp} 10.000 .000-\mathrm{Rp}$ 15.000.000, dan jantan dijual dengan harga Rp 24.000.000. Total ternak yang dijual pada kelompok tani Sumber Tani Makmur adalah 
12 ekor (15\%) dari total populasi (Tabel 7).

\section{Pola Pemasaran Ternak Sapi Potong}

Aktifitas pada upaya pola pemasaran peternakan merupakan suatu kegiatan yang menjadi penting, kegiatan ini bertujuan untuk dapat menyalurkan proses hilirisasi usaha peternakan dan sampai pada konsumen akhir. Lembaga pemasaran untuk memudahkan produsen dalam menyalurkan hasil produksi (Sukirno, 2005). Pola Pemasaran Ternak sapi potong di kelompok Tani Sumber Tani Makmur Desa Tangsi Duren berdasarkan cara penjualan ternak diperoleh penjualan ternak dapat berupa indukan, ternak potonng melalui blantik, namun demikian untuk cara penjualan anakan para peternak langsung ke konsumen. Namun berdasarkan kriteria penentuan harga didasarkan pada umur ternak dan jenis sapi dan selanjutnya peternak dan blantik sama-sama dapat menentukan harga ternak. Untuk waktu penjualan ternak biasanya peternak menjual ternak sapi berupa bibit jantan, indukan dan ternak potong dimana untuk umur bibit di jual saat ternak sapi umur 5 bulan.

Pembangunan pada sektor peternakan merupakan salah satu sistem yang terdiri pada sub-sistem; a. Sub-sistem hulu, kegiatan ekonomi yang menghasilkan produk; b. subsistem budidaya; c. sub-sistem agribisnis hilir kegiatan ekonomi yang mengolah komoditas peternakan primer menjadi produk olahan; dan d. sub-sistem jasa penunjang sistem pada kegiatan yang menyediakan jasa bagi ketiga sub-sistem lainnya. (Saragih, 2000).

\section{KESIMPULAN}

Berdasarkan pada hasil penelitian ini, maka dapat diambil kesimpulan bahwa:

1. Populasi keseluruhan ternak sapi potong yang dimiliki oleh kelompok Sumber Tani Makmur Desa Tangsi Duren sebanyak 81 ekor dalam satu tahun terakhir;

2. Manajemen ternk sapi potong yang ada pada kelompok Sumber Tani Makmur Desa Tangsi Duren sudah tergolong dalam pemeliharaan ternak secara intensif dan;
3. Pola pemasaran ternak sapi potong pada kelompok Sumber Tani Makmur Desa Tangsi Duren didasarkan dengan cara menjual ternak dengan kriteria penentuan harga dengan sistem waktu usaha dalam penjualan ternak.

\section{UCAPAN TERIMAKASIH}

Ucapan terimakasih kepada Program Pascasarjana Program Studi S2 Pengelolaan Sumberdaya Alam (PSDA) Fakultas Pertanian Universitas Bengkulu yang telah memberikan bantuan berupa dana penelitian, sehingga penelitian ini bisa terlaksana dengan baik dan lancar.

\section{DAFTAR PUSTAKA}

Abidin, Z. 2002. Kiat mengatasi permasalahan praktis "penggemukan sapi potong". Agromedia Pustaka. Jakarta.

Aksi Agraris Kanisus (AAK). 2011. Petujuk beternak sapi potong dan kerja. Kanisius. Yogyakarta.

Amin, M. N., U. A. Rokhayati, dan N. K. Laya .2019. Peran inseminasi buatan (IB) terhadap sistem perkawinan dikelompok tani ternak lembu karomah Kecamatan Taluditi Kabupaten Pohuwato. Jambura Journal of Animal Science. 1(2): 52-56

Direktorat Jenderal Peternakan dan Kesehatan Hewan. 2017. Populasi sapi potong dan konsumsi daging nasional di indonesia. Dirjen Peternakan dan Keswan. Departemen Pertanian. Jakarta.

Direktorat Jenderal Peternakan. 1998. Usaha Peternakan, Perencanaan, Analisis dan Pengolahan. Direktorat Jenderal Peternakan, Jakarta.

Direktorat Pembibitan Ternak. 2012. Pedoman Pelaksanaan Uji Performan Sapi Potong. Direktorat Jenderal Peternakan dan Kesehatan Hewan, Kementerian Pertanian. Jakarta. 
Diwyanto, K. 2008. Pemanfaatan sumber daya lokal dan inovasi teknologi dalam mendukung pengembangan sapi potong di indonesia. Pengembangan Inovasi Pertanian. 1(3): 173-188.

Hafez, E. S. E. and B. Hafez. 2013. Reproduction in farm animal.7th ed. Jhon Willey \& sons.

Kurniawati, R., P. N Gariri., M. V. Safitri., Maskur., Nurkholis, dan S. Nusantoro. 2019. Feeding evaluation of bali bulls' breeding (Bos sondaicus). Jurnal Nutrisi Ternak Tropis. 2(2): 47-50.

Murwanto, A. G. 2008. Karakteristik peternak dan tingkat masukan teknologi peternakan sapi potong di lembah prafi kabupaten manokwari. J. Ilmu Peternakan. 3(1): 9-15.

Rahardi, F. M. dan Hartono, R. 2003. Agribisnis peternakan. Penebar Swadaya, Jakarta.

Santoso, U. 2005. Tata Laksana pemeliharaan ternak sapi. Penebar Swadaya. Jakarta

Saragih. B. 2000. Agribisnis berbasis peternakan. Ed ke-2. USESE Foundation dan Pusat Pembangunan.
Institut Pertanian Bogor. Bogor.

Setiawan, B. D., Arfa'i, and Y. S. Nur. 2019. Evaluation of business management systems of bali cattle breeding integrated with the palm oil plantation in pasaman barat district, west sumatera province. Jurnal Ilmiah Peternakan Terpadu (JIPT). 7 (3): 276-286

Sugeng, Y. B. 2007. Beternak sapi potong. Penebar Swadaya. Jakarta.

Sukirno, S. 2005. Mikro ekonomi teori pengantar edisi ketiga. Rajagrafindo Persada. Jakarta.

Afriani, T., M. P. Agusta., Yurnalis, F. Arlina, dan D. E. Putra. 2019. Estimasi Dinamika Populasi dan Pembibitan Sapi Potong di Kecamatan Bayang Kabupaten Pesisir Selatan. Jurnal Peternakan Indonesia. 21(2): 130-142.

Toelihere, M. R. 1983. Tinjauan tentang Penyakit Reproduksi pada ternak ruminansia besar. Pusat Penelitian dan Pengembangan Peternakan Bogor, Bogor. 